\title{
Budaya Organisasi Pondok Pesantren Darussalam Blokagung Banyuwangi
}

\author{
Moh. Imam Khaudli ${ }^{1}$, Ikhsan Mubarok ${ }^{2}$ \\ e-mail : Imamkhaudli@iaida.ac.id ${ }^{1}$, bangikhsan98@gmail.com ${ }^{2}$ \\ Prodi Manajemen Pendidikan Islam \\ Institut Agama Islam Darussalam Blokagung Banyuwangi
}

\begin{abstract}
The objectives set from this research are (1) to find out the Organizational Culture that develops in the Darussalam Boarding School in Blokagung (2) to find out the main role of the Kiai as the main maker of the Culture of the Darussalam Boarding School in Blokagung Tgalsari Banyuwangi. This study uses descriptive qualitative research methods. In this study the researcher himself became (human instrument) with supporters of the interview guide grid, data collection is more emphasized on observation, interviews and documentation. The validity of the data in this study uses data triangulation. The results of his research on Organizational Culture at the Message Board of Darussalam Blokagung Tegalsari Banyuwangi were formed by several elements (1) the environment of the Darussalam Block Corn boarding school at its inception. (2) Values and the norms that have been taught by KH. Mukhtar Syafa'at Abdul Ghofur as the founder of a boarding school that has been sustainable until now. (3) Darussalam Blokagung pesantren rituals and traditions are one of the learning system activities and also other activities such as the typical 10 muharam activities, as well as other activities that have become an identity and shaped the organizational culture. (4) A role model or hero, the researcher considers this element to be the most important of the other elements because the characteristics and center of the creator in an organization are the leaders of the kiai (5) cultural network, this element is an informal communication between elements in Darussalam boarding schools Blokagung and develop by itself and become the identity of the cottage. And in Darussalam boarding school Blockagung kiai as the main leader and also plays a full role as (1) organizational activator (2) creator of Organizational Culture (3) cultural preserver and (4) as an agent of change.
\end{abstract}

Keywords: Role of Clerics, Organizational Culture

\section{Abstrak}

Tujuan yang ditetapkan dari penelitian ini adalah (1) untuk mengetahui Budaya Organisasi yang berkembang di Pondok Pesantren Darussalam Blokagung (2) untuk mengetahui peran utama Kiai sebagai pembentuk utama Budaya Organisasi Pondok Pesantren Darussalam Blokagung Tgalsari Banyuwangi. Penelitian ini menggunakan metode penelitian deskriptif kualitatif.dalam penelitian ini peneliti sendiri yang menjadi (human instrument) dengan pendukung dari kisi-kisi pedoman wawancara, pengumpulan data lebih ditekankan pada observasi, wawancara dan dokumentasi.Keabsahan data dalam 
penelitian ini menggunakan Trianggulasi data. Hasil penelitiannya Budaya Organisasi di Pondok Pesanren Darussalam Blokagung Tegalsari Banyuwangi terbentuk atas beberapa unsur (1)Lingkungan pondok pesantren Darussalam Blokagung di awal berdiri. (2) Nilai-nilai dan ketepan norma-norma yang telah di ajarkan oelh KH. Mukhtar Syafa'at Abdul Ghofur sebagai pendiri pondok pesantren yang telah lestari hingga kini. (3) Ritual dan tradisi pondok pesantren Darussalam Blokagung salah satunya kegiatan sistem pembelajaran dan juga kegiatan lain seperti halnya kegiatan 10 muharam yang khas, serta kegiatan lain yang telah menjadi identitas dan membentuk budaya organisasi. (4) Panutan atau pahlawan, peneliti menganggap unsur ini paling penting dari unsur-unsur lain karena karakteristik serta pusat pencipta dalam suatu organisasi adalah seorang pemimpin yang dianut yaitu kiai (5) jaringan budaya, unsur ini sebagai komunikasi informal antar elemen di pondok pesantren Darussalam Blokagung dan berkembang dengan sendirinya serta menjadi identitas pondok. Di Pondok Pesantren Darussalam Blokagung kiai sebagai pimpinan utama dan juga berperan penuh sebaga (1) penggerak organisasi (2) pencipta Budaya Organisasi (3) pemelihara budaya dan (4) sebagai agen perubahan.

Kata Kunci : Peran Kiai, Budaya Organisasi

\section{A. Pendahuluan}

\section{Latar Belakang Masalah}

Budaya organisasi adalah sesuatu yang selalu ada di setiap organisasi salah satunya lembaga pendidikan islam pondok pesantren, Menurut Robbins (1996:289), budaya organisasi adalah suatu persepsi bersama yang dianut oleh anggota-anggota organisasi itu, budaya organisasi sangat penting keberadaannya untuk kelangsungan kehidupan dan kesuksesan suatu organisasi.

Penerapan budaya organisasi memiliki tujuan agar seluruh individu dalam sebuah kelompok organisasi dapat mematuhi dan berpedoman pada nilai, keyakinan dan presepsi bersama yang telah disepakati dan dilaksanakan oleh suatu organisasi, perilaku individual atau kelompok dalam suatu organisasi sangat berpengaruh bagi pencapaian prestasi organisasi serta juga dapat berpengaruh pada efektivitas kemajuan organisasi tersebut. Sehingga budaya organisasi yang dikelola dengan manejemen yang baik maka pastinya akan berpengaruh pada perilaku organisasi yang positif dan produktif bagi organisasi.

Pondok pesantren adalah Lembaga Pendidikan islam yang telah bertahun-tahun bergerak dan menjadi wadah untuk memperdalam

Budaya Organisasi Pondok Pesantren Darussalam Blokagung Tegalsari Banyuwangi

Muh. Imam Khaudli, Ikhsan Mubarok 
Pendidikan islam bagi umat islam, dalam perkembangan zaman yang terus mengalami kemajuan secara pesat mengakibatkan pondok pesantren harus terus bergerak mengikuti arus moderenisasi dan telah dihadapkan dengan tantangan zaman serta permasalahan yang semakin kompleks, tantangan di era medernisasi ini dapat menjadi tolak ukur pondok pesantren sejauh mana dapat mengatasi dan dapat berkembang di era modernisasi yang telah berkembang pesat.

Pentingnya budaya organisasi sebagai kekuatan sebuah oragniasai dalam sebuah pendidikan islam khususnya pesantren sangat penting, nurcholis majid telah berkata bahwasanya pesantren adalah artefak peradaban Indonesia yang dibangun sebagai institusi pendidikan keagamaan bercorak tradisonal, unik dan Indigenous, dan hal tersebut telah ada dan menjadi penguat pondok pesantren Darussalam Blokagung yang mempunyai budaya organisasi berupa nilai dan norma serta keunikan tersendiri yang pastinya sangat menarik untuk diteliti.

Pondok pesantren Darussalam Blokagung juga tidak lepas atas peran Kiai sebagai pimpinan dan pengasuh pondok pesantren dalam membangun budaya pesantren untuk membentuk karakter lembaga sebagai identitas yang khas dan menjadi pembeda dengan lembaga lainnya, Peran Kiai juga telah menumbuhkan tradisi keilmuan dan kejelasan sistem pengelolaan pendidikan pondok pesantren yang khas dan unik sebagai identitas utama pondok pesantren Draussalam Blokagung.

Dari uraian diatas Peneliti sangat tertarik untuk mengkaji budaya organisasi karena teori ini banyak dibahas dan masih dalam bagian pembahasan manajemen, dan titk fokus penelitian ini adsalah pondok pesantren Darussalam blokagung dengan fokus pembahasan pada budaya organisasi pondok pesantren dan peran kiyai sebagai pembentuk budaya organisasi pondok pesantren Darussalam Blokagung, yang menjadikan pesantren tersebut besar dan berkembang pesat hingga saat ini, dalam hal ini peneliti tertarik untuk mengambil judul dengan tema "Budaya Organisasi Pondok Pesantren Darussalam Blokagung Tahun 2020”.

Budaya Organisasi Pondok Pesantren Darussalam Blokagung Tegalsari Banyuwangi

Muh. Imam Khaudli, Ikhsan Mubarok 


\section{Rumusan Masalah}

Dari latar belakang di atas dapat peneliti kemukakan beberapa rumusan masalah yang harus diteliti sesuai judul yaitu:

a. Bagaimana Budaya Organisasi Pondok Pesantren Darussalam Blokagung Tahun 2020?

b. Bagaimana Peran Kiyai dalam membentuk Budaya Organisasi Pondok Pesantren Darussalam Blokagung Tahun 2020?

\section{Tujuan Penelitian}

a. Untuk Mengetahui Budaya Organisasi Pondok Pesantren Darussalam Blokagung Tahun 2020

b. Untuk Mengetahui Peran Kiyai dalam memelihara Budaya Organisasi Pondok Pesantren Darussalam Blokagung Tahun 2020

\section{Batasan Masalah}

Batasan masalah yang dimaksud dalam penelitian ini untuk membatasi permasalahan yang akan diteliti. Agar tidak terjadi pelebaran masalah yang akan dibahas. Adapun dalam penelitian ini batasan masalah yang akan dibahas antara lain :

a. Penelitian ini bertempat di Pondok Pesantren darussalam Blokagung Tegalsari Banyuwangi tahun 2020.

b. Budaya organisasi yang diteliti adalah khusus pada budaya pesantren yang berkembang serta karakteristik utama Pondok Pesantren.

c. Penelitian lain juga yaitu terkait peran kiyai dalam memelihara budaya organisasi Pondok Pesantren dengan unsur yang ada dibawahnya seperti ustazd dan santri.

\section{Manfaat Penelitian}

a. Teoritis

Penelitin ini diharapkan dapat menambah ilmu pengetahuan terutama yang berkaitan dengan budaya organisasi pondok pesantren.

b. Praktis

1) Dapat di gunakan sebagai bantuan dalam memaksimalkan pencapaian organisasi di Lembaga Pondok Pesantren 
2) Penelitian ini di harapkan bisa menjadi rujukan bagi peneliti lain yang akan meneliti dalam tema terkait.

\section{B. Landasan Teori}

\section{Budaya Organisasi}

Budaya organisasi adalah: suatu persepsi bersama yang dianut serta pola dasar yang diterima oleh organisasi untuk bertindak dan memecahkan masalah dan mempersatukan anggota-anggota organisasi.Selanjutnya madzhab Adaptationist school melihat budaya dari apa yang bisa diobservasi baik dari bangunan organisasi seperti arsitektur atau tata ruang bangunan fisik sebuah organisasi. Selanjutnya yang terakhir adalah Realist School melihat budaya organisasi adalah budaya yang kompleks yang tidak bisa dipahami hanya dari pola perilaku orang-orang saja tetapi juga sumber perilaku tersebut.

Budaya organisasi mempunyai beberapa Karakteristik yang menjadi identitas utama organisasi, ada beberapa beberapa karakteristik budaya organisasi menurut Heri Sulaksono (2015: 06) sendiri antara lain adalah :

a. Perhatian pada hal-hal rinci

b. Berorentasi pada hasil daripada proses dan teknis untuk mencapai hasil tersebut.

c. Berorentasi pada orang

d. Berorentasi pada

e. Mengutamakan sikap agresif dari pada bersikap santai.

f. Memperhatikan stabilitas

\section{Pondok Pesantren}

Pesantren adalah sebuah kawasan yang khas dan khusus dengana ciricirinya yang tidak di miliki oleh tempat atau kawasan lain .Abdurrahman Wahid pernah menyebutkan dan dikutip daribuku Zamakhsyari Dhofier, (44-60) menyebut pesantren adalah sebuah sub-kultur tersendiri, denganunsur-unsur yang terdapat dalam sistem pendidikan pesantren secara 
tradisional yang menjadikannya khas seperti adanya unsur kiai, santri, masjid, pondok dan pengajaran kitab- kitabklasik.

\section{Peran Kiai dalam Membentuk Budaya Organisasi}

Kiai adalah sosok atau tokoh sentral dibalik kemajuan pondok pesantren, menurut Saiful ahyar lubis menyatakan bahwa kiai adalah tokoh sentral dalam suatu pondok pesantren, maju mundurnya pesantren tergantung pada sosok kiai yang wibawa dan karismatik. Kiai mempunyai tugas di antaranya adalah:

a. Melaksanakan tablikh dan dakwah untuk membimbing umat.

b. Melaksanakan amar ma`ruf nahi munkar.

c. Memberikan contoh dan teladan yang baik kepada masyarakat

d. Memberikan penjelasan kepada masyarakat terhadap berbagai macam ajaran Islam yang bersumber dari al-Qur'an dan al- Sunnah.

e. Memberikan Solusi bagi persoalan-persoalan umat

f. Membentuk orientasi kehidupan masyarakat yang bermoral dan berbudi luhur.

g. Menjadi rahmat bagi seluruh alam

\section{Penelitian Terdahulu}

a. Jurnal Dedik (2018) Dengan judul budaya organisasi pondok pesantren tarbiyah Islamiyah Ar-Raudhatul Hasanah Paya Bundung Medan, penelitian ini menggunakan Kualitatif, dalam penelitian tersebut ditemukan sejarah keberadaban pondok pesantren ArRaudhatul Hasanah, dan ada dua budaya yang menjadi factor utama keberhasilan pendidikan di pesantren yaitu budaya kasat mata ( tangible culture) dan budaya tidak kasat mata (itangible culture).

b. Skripsi Yasri Yusniar (2018) dengan judul Penerapan Budaya Pesantren Dalam Membangun Karakter Santri Di Perguruan Dinniyah Putri Kecamatan Gedong Tataan Kabupaten Pesawaran, Penelitian yang dilakukan penulis merupakan penelitian lapangan yang bersifat deskriptif, yaitu yang semata-mata menggambarkan secara tepat tentang penerapan budaya pesantren di Perguruan Dinniyah Putri Lampung di Gedong Tataan dalam Membangun karakter santri.

Budaya Organisasi Pondok Pesantren Darussalam Blokagung Tegalsari Banyuwangi

Muh. Imam Khaudli, Ikhsan Mubarok 
Populasi yang ada di Perguruan Dinniyah Putri berjumlah 387orang dan yang menjadi sampel 7 orang. Adapun pengambilan sampel yang penulis gunakan adalah tekhnik purposive sampling yang berdasarkan pada ciri-ciri dan sifat-sifat tertentu.Penelitian ini menggunakan tekhnik pengumpulan data observasi sebagai metode utama, metode intervie dan metode dokumentasi sebagai metode penunjang.Data dilapangan menunjukan bahwa pengurus Perguruan Dinniyah Putri telah berusaha secara optimal untuk merealisasikan proses penerapan budaya dalam membangun karakter santri dengan membagi tugas kepada ustadzah / ustadz yang berpengalaman dan memberikan materi-materi yang sangat menunjang di bidang akhalak.

Berdasarkan penelitian diatas, meskipun objek memiliki kesamaan dengan penelitian sebelumnya yaitu sama-sama dilakukan di pondok pesantren, akan tetapi Budaya Pondok Pesantren Darussalam Blokagung Tegalsari Banyuwangi merupakan pondok terbesar di Banyuwangi dengan banyaknya jumlah santri serta memiliki histori tersendiri dan ciri khas perpaduan Pendidikan salafiyyah dan Pendidikan formal, Adanya beberapa perbedaan tersebut diharapkan dapat memberi indikasi perbedaan hasil penelitian dengan penelitian-penelitian sebelumnya.

\section{Metode Penelitian}

\section{Jenis Penelitian}

Penelitian ini menggunakan jenis penelitian deskriptif kualitatif yaitu penelitian yang sifatnya mendeskripsikan atau menggambarkan hasil dari penelitian sebagai jawaban dari rumusan masalah. Penelitian ini peneliti terfokus pada Budaya Organisasi Pondok Pesantren Darussalam Blokagung Tegalsari Bnyuwangi.

\section{Lokasi Penelitian}

Lokasi penelitian ini ialah Pondok Pesantren Darussalam Blokagung Tegalsari Banyuwangi.

\section{Sumber Data}

Budaya Organisasi Pondok Pesantren Darussalam Blokagung Tegalsari Banyuwangi

Muh. Imam Khaudli, Ikhsan Mubarok 
Sumber data dalam penelitian ini ada dua yaitu: sumber data primer dan sekunder.Sumber data primerdiperoleh melalui wawancara langsung kepada bagian kepesantrenan dan pengurus. Wawancara dengan beberapa informan akan mendapatkan informasi terkait Budaya Organisasi Pondok Pesantren Darussalam Blokagung Tegalsari Banyuwangi.Sedangkan Sumber data sekunderdidapatkan dari pengurus pondok Pesantren untuk mendapatkan data terkait Budaya Organisasi.

\section{Teknik Pengumpulan Data}

Penelitian ini menggunakan 3 teknik pengumpulan data yaitu: observasi,wawancara dan dokumentasi sesuai pendapat Sugiyono (2015: 309) menyatakan bahwa "dalam penelitian kualitatif pengumpulan data dilakukan pada kondisi yang alami, sumber data primer, dan pengumpulan datanya lebih ditekankan pada observasi, wawancara, dan dokumentasi.

\section{Analisis data}

Penelitian ini menggunakan teori Milles dan Hubermen dengan menggunakan interaktiftiga model yaitu :Kondensasi data, penyajian data dan pengambilan keputusan.

\section{Hasil Penelitian}

\section{Data Tentang Budaya Organisasi Pondok Pesantren Darussalam} Blokagung Tegalsari Banyuwangi

Beberapa unsur pembentuk budaya organisasi Pondok Pesantren Darussalam Blokagung Tegalsari Banyuwangi:

a. Lingkungan Organisasi

Pondok Pesantren Darussalam Blokagung berada di wilayah dusun Blokagung di banyuwangi selatan penduduk mayoritas semula sebelum ada pesantren adalah beragama hindu. Lingkungan tersebut adalah cikal bakal berdirinya pondok pesantren Darussalam Blokagung.

b. Nilai-Nilai

Budaya Organisasi Pondok Pesantren Darussalam Blokagung Tegalsari Banyuwangi

Muh. Imam Khaudli, Ikhsan Mubarok 
Budaya yang telah ada pada Pondok Pesantren Darussalam Blokagung juga tidak lepas atas nilai-nilai dan norma-norma yang melekat pada pesantren, seperti halnya moto utama Pondok Pesantren Darussalam Blokagung yaitu "Menjaga perkara lama yang baik dan mengambil perkara baru yang lebih baik" dan moto tersebut telah menjadi jati diri dan identitas Pondok Pesantren Darussalam Blokagung.

c. Panutan atau Pahlawan

Lembaga pondok pesantren Darussalam Blokagung juga telah mempunyai panutan sebagai sosok utama pembentuk budaya organisasi pondok pesantren yaitu pendiri pondok pesantren Darussalam Blokagung dan para pengasuh atau kiai pondok peantren Darussalam Blokagung.

d. Ritual

Kegiatan pembelajaran sekolah pagi yang selalu di awali dengan istighosah qosiroh, serta kegiatan solat malam, kegiatan jaga malam bagi santri putra serta kegiatan pengajian ahad legi dan kegiatan 10 muharram yang telah menjadi ciri khas pondok pesanren Darussalam Blokagung dan menjadi keunikan tersendiri bagi pondok pesantren.

e. Jaringan Budaya

Pondok Pesantren Darussalam Blokagung yang mempunyai idenitas berupa proses komunikasi informal antara santri dan kiai serta santri kepada ustadz, yang berbeda dengan lembaga pendidikan lain.

\section{Data tentang peran kiai dalam membentuk budaya organisasi} Pondok Pesantren Darussalam Blokagung Tegalsari Banyuwangi

a. Sebagai penggerak organisasi

Penggerak utama organisasi pondok pesantren Darussalam Blokagung adalah dari unsur para pengasuh pondok pesantren Darussalam Blokagung.

b. Pencipta budaya

Lembaga pesantren ini KH. Mukhtar Syafaat Abdul Ghofur adalah pendiri sekaligus pencipta budaya pesantren Darussalam 
Blokagung, baik itu budaya dalam proses pembelajaran ilmu agama mulai dari sistem sorogan, bandongan serta sekolah madrasah diniyyah yang masih tetap eksis dan menjadi pendidikan utama di pondok pesantren Darussalam Blokagung Banyuwangi.

c. Pemelihara budaya

Pondok Pesantren tetap kuat dan eksis hingga saat ini serta budaya Pesantren yang lama dan yang baru tetap terjaga dan berjalan bersama dengan era modernisasi yang semakin kuat hingga saat ini.

d. Sebagai agen perubahan

Bidang pendidikan yang saat ini berkembang sangat pesat mulai dari sekolah Dasar, sekolah menengah serta sekolah menengah atas dan saat ini juga telah ada perguruan tinggi dan semua ini adalah bentuk inovasi para kiai atau pengasuh Pondok Pesantren Darussalam Blokagung dalam bersaing di era Modernisasi saat ini.

\section{E. Pembahasan}

\section{Budaya Organisasi Pondok Pesantren Darussalam Blokagung}

a. Lingkungan organisasi sebagai salah satu unsur pembentuk budaya organisasi pondok pesantren Darussalam Blokagung.

b. Nilai-nilai dan norma-norma pondok pesantren terbentuk atas pengaruh dari para pengasuh pondok pesantren serta menjadi identitas utama pondok pesantren Darussalam Blokagung.

c. Panutan utama pondok pesantren Darussalam Blokagung adalah para kiai atau para pengasuh pondok pesantren Darussalam Blokagung.

d. Ritual dan acara rutinan pondok pesantren Darussalam Blokagung telah banyak menjadi tradisi dan identitas pondok pesantren Darussalam Blokagung.

e. Jaringan Budaya dalam pondok pesantren Darussalam Blokagung berlangsung dalam komunikasi informal.

\section{Peran Kiai Dalam Membentuk Budaya Organisasi pondok} Pesantren Darussalam Blokagung 
a. Peran kiai sebagai penggerak organisasi sangat penting bagi pondok pesantren Darussalam Blokagung.

b. Peran kiai dalam pondok pesantren Darussalam Blokagung juga berperan penting sebagai pencipta budaya organisasi.

c. Peran kiai sebagai pemelihara budaya di pondok pesantren Darussalam Blokagung juga berlangsung bersama dengan para ustadz dan para pengurus pesantren.

d. kiai juga sangat berperan sebagai agen perubahan dalam pembentukan budaya organisasi pondok pesantren Darussalam Blokagung.

\section{F. Kesimpulan}

\section{Budaya Organisasi Pondok Pesantren Darussalam Blokagung}

Budaya organisasi pondok pesantren Darussalam Blokagung terbentuk atas beberapa unsur salah satunya yang paling berpengaruh adalah lingkungan pondok pesantren yang menuntut pendirian pesantren serta budaya yang berkembang didalamnya harus sesuai dengan budaya dan tradisi pondok pesantren Darussalam Blokagung.

Nilai-nilai yang terbentuk serta telah menjadi presepsi dan pedoman pondok pesantren Darussalam Blokagung saat ini berawal dari pengaruh pendiri pondok pesantren yaitu KH. Mukhtar Syafa'at, yang hingga saat ini masih terjaga dan lestari dengan baik, seperti halnya pembentukan slogan dan moto pondok pesantren yang menjadi jati dri utama pondok pesantren hingga saat ini tidak terlepas dari pengaruh lingkungan pondok pesantren dan juga pengaruh para kiai dan menjadi visi utama pondok pesantren kedepan.

\section{Peran Kiai Dalam Membentuk Budaya Organisasi pondok Pesantren Darussalam Blokagung}

Peran kiai atau pemimpin pondok pesantren sebagai pembentuk budaya pondok pesantren Darussalam Blokagung sangat berpengaruh, seiring berjalannya waktu pondok pesantren Darussalam hingga saat ini bias pesat dan maju tidak lepas atas peran kiai sebagai penggerak oganisasi, serta budaya pesantren dengan nilai-nilai khas yang menjadi 
identitas pondok pesantren Darussalam Blokagung tercipta atas peran kiai sebagai pimpinan pondok pesantren Darussalam Blokagung.

Budaya Pesantren dengan nilai-nilai luhurnya hingga saat ini masih dijaga dengan baik oleh para kiai serta dibantu oleh para ustadz dan pengurus pesantren, dan juga tak lupa perubahan dan inovasi tetap dilakukan sesuai dengan slogan pondok pesantren Darussalam Blokagung yaitu "menjaga perkara lama yang baik dan mengambil perkara baru yang lebih baik" dan higga saat ini perubahan terus dilakukan sepeti halnya bidang pendidikan yang selalu ada pembaharuan,sistem pembelajaran yang modern serta tetap menjaga budaya lama salah satunya pembelajaran agama di madrasah diniyyah yang masih terjaga, kegiatan pengajian sorogan, bandongan dan wetonan yang masih terpelihara dengan baik.

\section{G. Daftar Pustaka}

Dhofier, ZamakhsyarI. 1981. Tradisi Pesantren: Studi tentang Pandangan Hidup Kiyai. Jakarta: LP3ES

Falikhatun, 2003. Jurnal Emperika. Vol. 16. No. 2, Pengaruh Budaya Organisasi, LocusOf Control, Penerapan Sistem Informasi Terhadap Kinrja Aparat Unit - Unit Pelayanan Publik.

Mardiyah, 2012. Kepemimpinan Kiyai dalam Mendukung Budaya Organisasi. Yogyakarta: Aditya Media

Sutrisno, Edy. 2019. Budaya Organisasi. Jakarta: Prenada Media Grup

Sulaksono Heri, 2015. Budaya Organisasi dan Kinerja. Yogyakarta: CV. Budi Utama

Sugiyono, 2008. Metode Penelitian Pendidikan. Bandung: Alfabeta

Syaifuddin Zuhri, Muhammad. 2011, Budaya Pesantren dan Budaya Pendidikan Karakter. Semarang: IAIN Walisongo

Tika, H. Moh. Pabundu. 2006. Budaya Organisasi dan Peninkatan Kinerja Perusahaan. Jakarta: Bumi Aksara

Raport Santri. 2020. Pondok Pesantren Darussalam Blokagung Banyuwangi

Budaya Organisasi Pondok Pesantren Darussalam Blokagung Tegalsari Banyuwangi

Muh. Imam Khaudli, Ikhsan Mubarok 
Robbins, Stephen P. 2006. Perilaku Organisasi, Edisi Bahasa Indonesia, Jilid Kedua. New Jersey: Prentice Hell

Rivai, Veithzal. 2018. Manajemen Sumber Daya Manusia untuk Perusahaan, Bandung: Alfabeta 